\title{
Making Sense of Business and Community in Hollywood Films
} 1928-2016

\author{
Hansen, Per H.; Magnussen, Anne
}

Document Version

Accepted author manuscript

Published in:

Business History Review

DOI:

10.1017/S000768051800003X

Publication date:

2018

\section{License \\ CC BY-NC-ND}

Citation for published version (APA):

Hansen, P. H., \& Magnussen, A. (2018). Making Sense of Business and Community in Hollywood Films: 1928-2016. Business History Review, 92(2), 307-337. https://doi.org/10.1017/S000768051800003X

Link to publication in CBS Research Portal

\section{General rights}

Copyright and moral rights for the publications made accessible in the public portal are retained by the authors and/or other copyright owners and it is a condition of accessing publications that users recognise and abide by the legal requirements associated with these rights.

Take down policy

If you believe that this document breaches copyright please contact us (research.lib@cbs.dk) providing details, and we will remove access to the work immediately and investigate your claim. 


\title{
Making Sense of Business and Community in Hollywood Films: 1928-2016
}

\section{Per H. Hansen and Anne Magnussen}

\author{
Journal article (Accepted manuscript *)
}

\section{Please cite this article as:}

Hansen, P. H., \& Magnussen, A. (2018). Making Sense of Business and Community in Hollywood Films: 19282016. Business History Review, 922), 307-337. 001: 10.1017/S000768051800003X

This article has been published in a revised form in Business History Review DOI: http://dx.doi.org/10.1017/S000768051800003X

This version is published under a Creative Commons CC-BY-NC-ND. No commercial re-distribution or re-use allowed. Derivative works cannot be distributed. (C) The President and Fellows of Harvard College २०1८

* This version of the article has been accepted for publication and undergone full peer review but has not been through the copyediting, typesetting, pagination and proofreading process, which may lead to differences between this version and the publisher's final version AKA Version of Record. 
Per H. Hansen and Anne Magnussen

Making Sense of Business and Community in Hollywood Films, $1928-2016$

We analyze how Hollywood films from 1928 to 2016 represented business within a broad historical and business context. We argue that the films actively contributed to audiences' sensemaking processes and to how different groups perceived the role of business in society. We advance the idea that films provided cultural blueprints to be used by viewers for their own understanding, identification, and practices in relation to business in its historical context, particularly during periods of uncertainty, crisis, and instability when many films addressed deeper societal concerns about the role of business.

Keywords: Hollywood film, sensemaking, stakeholder versus shareholder view of the company, corporate governance, finance and business, entrepreneurship 
In the 2011 movie Margin Call, John Tuld, the CEO of a large investment bank, orders a manager to unload collateralized debt obligations (CDOs) on the market for billions of dollars to save the bank. Afterward, when the manager is critical of the action, Tuld responds cynically that financial crises are a permanent feature of capitalism: “They're just the same thing over and over. We can't help ourselves, and you and I can't control it, stop it, slow it, or even ever so slightly alter it."

Margin Call_-together with films such as Wall Street: Money Never Sleeps, Too Big to Fail, The Wolf of Wall Street, and The Big Short-directly addresses the search for meaning and explanation that followed the financial crisis of 2007-2008. In 2016 the New York Times reported that "there is a growing audience for movies . . . that address the misdeeds and systemic failures that brought the economy to the edge of collapse eight years ago." Arguably, Hollywood films' narrative emplotment and their huge reach in terms of audience suggest that their potential to shape viewers' understanding of the crisis is bigger than that of the countless academic papers published on the topic or, say, the Financial Crisis Inquiry Commission's Financial Crisis Inquiry Report from $2011 .^{2}$

Interestingly, while Tuld argued that crises are an inherent part of the financial system, the report by the Financial Crisis Inquiry Commission (FCIC) concluded that "this financial crisis was avoidable."3 According to Robert A. Rosenstone, history films should be evaluated in terms not of their truthfulness, but of whether their overall vision "has something meaningful and important to say about our past." ${ }^{, 4}$ In parallel, the issue is not whether the representation of business in Margin Call or other Hollywood films is true, but whether the films' vision of business is meaningful and important.

In this article we use a "sensemaking" approach to argue that Hollywood films ascribe meaning to business through narrative plots that legitimize certain practices and world views while marginalizing others. ${ }^{5}$ In creating meaning, films provide a narrative vision that viewers can use to make sense of, for instance, financial crises. A viewer's interpretation of films depends on his or her world view, which is related to the specific group or community that the viewer identifies with. ${ }^{6}$

At a prescreening of The Wolf of Wall Street in the financial district of Manhattan, bankers were among the audience that reportedly exhibited a "gleeful reaction to ... [Jordan Belfort's] behavior and legal wrongdoings," implying that the traders constituted a community that identified with Belfort. ${ }^{7}$ Twenty-five years earlier, the movie Wall Street inspired a "generation of would-be Gordon Gekkos" including now law and finance professor Frank Partnoy, who watched the movie in 1987 and "decided he wanted to be part of it." In contrast, Pat Huddleston, a young law school 
graduate at the time, watched the same movie and decided to join the SEC as a regulator. More generally, many Wall Streeters recognized at least some resemblance to the real thing, and many young investment bankers began to dress like Gordon Gekko; sales of suspenders doubled after the release of the film. ${ }^{8}$

According to anthropologist Grant McCracken, members of a community act in conformity with a cultural blueprint and, in doing so, they create or reproduce cultural categories: "Individuals continually play out categorical distinctions, so that the world they create is made consistent with the world they imagine." 9 Thus, we see films as performative because they contribute to the cultural blueprint in society or other communities. Not only do Hollywood films reflect reality, but they are important sensemaking vehicles and their narratives are used in shaping identities, perceptions, and practices within epistemic communities - whether as investment bankers, unionized workers, entrepreneurs, managers, or "organization men."10

The potential of films to shape individual and group perceptions, identities, and practices is hardly restricted to those about the recent financial crisis. ${ }^{11}$ For instance, corporate movies of the 1950s such as Executive Suite (1954), Patterns (1956), The Power and the Prize (1956), and The Man in the Gray Flannel Suit (1956) surely influenced the public's understanding and view of the big U.S. corporations and, by providing a moral and a blueprint for thinking and acting, probably contributed to shaping the "organization man" and his workplace practices, including gendered behavior. Though the focus of this study is new to business history, a few historical studies of business films have analyzed different topics within specific historical periods. ${ }^{12}$ However, most are not focused on the question of how films make sense of business and legitimize or delegitimize business organizations and their practices in a long-term historical context. ${ }^{13}$

In this article, we use the ideas outlined above to analyze how Hollywood films have made sense of business from 1928 to 2016, and we discuss how this may have affected the audience's perception of business. In particular, we focus on the sensemaking of business films in relation to radical change and instability (as in the case of the Great Depression or the latest financial crisis) and to cases of uncertainty (such as in the market for corporate control in the 1980s).

In terms of periodization, we distinguish between stable and transitional periods. Stable periods are defined by a relative stability of meanings and constitute cultural, political, and economic regimes where one narrative is dominant, albeit alongside marginal or opposing narratives. During a transitional period there is widespread uncertainty as to what direction the business world, and society more generally, should take. The Great Depression and the financial 
crisis of 2007-2008 are cases in point. This increased uncertainty results in an intensified struggle about making sense of the time and circumstances and about identifying, producing, and legitimizing a new direction for the future. The struggle is visible in many realms of society: in the media, in the theoretical and academic literature about business, and in popular culture such as Hollywood films.

We consider five periods: crisis and war (1928 to 1949); big corporations and the welfare state (1950 to 1969); disillusion and social criticism (1970 to 1985); neoliberalism and financialization (1986-2008), and the post-financial crisis period (2009 to present). ${ }^{14}$ We use this periodization to contextualize the eighty-one Hollywood films we have singled out. All of the Hollywood films selected have the business world as their main focus or as an important setting, which typically means that the main conflict relates to a company or an industry in a significant way (see Appendix). ${ }^{15}$ In our specific discussion of how the films make sense of business, we identify which values the films represent through a narrative analysis with focus on events, actors, time, and location. ${ }^{16}$ In addition, we use what we refer to as big speeches, typically located at a decisive point in the film, that spell out the film's key values and vision. We relate each film to the historical context of its time period as well as to some of that period's paradigmatic academic literature about business.

We offer examples of big speeches and central scenes from key films from each period and use other films from the same period to contextualize and support our readings and conclusions. ${ }^{17}$ We do not consider the screenwriters' or directors' intentions, or how the Hollywood system influenced the films' representation. Nor do we consider whether and how films can serve as useful sources for historians, though they undoubtedly can. ${ }^{18}$

Crisis and War, from 1928 to 1949

The period from the late 1920 s to the late 1940s was a long transitional period characterized by economic depression, cultural conflicts, political and social polarization and extremism, and, not least, World War II. One of the main characteristics of this period was a deep distrust of big business, finance, and business leaders, prompted by the Wall Street crash and the Great Depression. A theoretical literature emerged that tried to explain the existence of and problems related to large firms. Adolf Berle and Gardiner Means's presentation of the public corporation as a social institution that should (but did not) focus on stakeholder interests, and Ronald Coase's 
explanation of the existence of the firm and transaction costs as drivers of integration were important contributions. ${ }^{19}$ Perhaps more pertinent to the Hollywood films of the time was Frederick Winslow Taylor's so-called scientific management theory and the Pecora inquiry of the 1929 Wall Street crash. ${ }^{20}$

Quite a few films from this period focused on business, and many were critical of big business, industry, and finance in ways that related to the literature just mentioned. Thus, The Crowd (1928), Modern Times (1936), The Power and the Glory (1933), and Citizen Kane (1941) zoomed in on the damaging alienation of the city and big business. In contrast, American Madness (1932), An American Romance (1944), It's a Wonderful Life (1946), and All My Sons (1948) focused on the positive values of family, community, and small-town business. ${ }^{21}$

According to The Crowd and Modern Times, business was connected to city-based bureaucratic and hierarchical routines and to manufacturing. Preindustrial America was more or less explicitly represented as the holder of true values and the good life. ${ }^{22}$ In The Crowd, protagonist John Sims's failed efforts to become "somebody big" constitutes the film's main theme. Sims is full of confidence on his way to New York from small-town America, but after a series of deceptions and disappointments, he is left on the margin of society with both his ambitions and family in tatters. ${ }^{23}$ Modern Times is a similarly strong critique of big-city work life. This is made clear at the film's beginning, where factory and white-collar workers are likened to sheep. As a counterimage, the film ends with the protagonist and his girlfriend leaving the city, walking toward the horizon and supposedly small-town America.

While The Crowd and Modern Times deal with ordinary folks who lose out to the crowd and give up hope of making it in the big city or the corporation, The Power and the Glory and Citizen Kane portray two successful businessmen who die alone and disillusioned. Tom Garner and Charles Foster Kane are tragic figures despite their success as managers of the largest railroad in the United States and a newspaper empire, respectively,. Kane dies longing for his childhood amid the many material possessions he has amassed, while Garner kills himself having realized that his second wife has had an affair with his son. Kane is driven by his own lust for power, while Garner's route to the top goes through his first wife's ambitions. Despite significant differences, both characters are strong and ruthless business managers who fail to understand the importance of family and community. ${ }^{24}$

In contrast, American Madness and It's a Wonderful Life place a high value on community, small-town America, cooperation, and national coherence, while the negative counterimage is either 
only implied or limited to a key villain. ${ }^{25}$ In American Madness, loyal employees and small-scale businessmen avert a run on the local bank after the board and the bank's wealthy customers have turned down the bank manager's request for assistance. American Madness is similar to the socially critical films described above in that it holds up the close-knit small-town America as the ideal, but the role of business is represented in a markedly different way. In this film, some businesses are good - a point made through the distinction between big, inhumane, profit-oriented firms, as featured in The Power and the Glory and Citizen Kane, and the local businesses that depend on the community and vice versa.

In It's a Wonderful Life, George Bailey runs a small building and loan society founded by his father. In the early 1930s there is a run on the institution, which George succeeds in averting only by canceling his honeymoon and paying out his and his bride's own money to the depositors. It's a Wonderful Life introduces the small-scale businessman who is part of and works for the community. In his big speech at a board meeting where the evil and lonely capitalist Mr. Potter tries to take control of the Building and Loan, George defends his father and his father's legacy, admitting to Potter that Peter Bailey had been no businessman, but, in contrast to Potter, he had cared about people — and "in my book, he died a much richer man than you'll ever be!"

The dynamics between generations constitute an important feature in these films. George's father is crucial as the small-scale businessman who started up the local business, but George represents the young generation and the future of both the business and the local community. At first, George dreams of pursuing his personal ambitions outside of Bedford Falls, but the crisis at the Building and Loan makes him realize that it is more important to continue his father's legacy and serve the community. Years later, there is another showdown between George and Potter, who through an act of dishonesty threatens bankruptcy for the Building and Loan. With the help of George's family and the local community, it all ends well. In narrative terms, the hero is the main focus in American Madness and It's a Wonderful Life. In contrast, The Crowd, The Power and the Glory, Modern Times, and Citizen Kane have no real heroes-instead, they focus mainly on lonely villains and their victims.

Several of the films from the 1940s combine entrepreneurship, leadership, and generational conflict, including An American Romance and All My Sons. In the former, the generational question is framed within a classic American Dream story of the immigrant entrepreneur: in this case, Stefan Dangos, who comes to the United States with nothing and ends up with a large and thriving automobile company. His son is of the second generation, both in the country and in the company, 
and his formal training as an engineer contrasts with the self-made success of the father. The son works on the shop floor to learn the ropes of the company. Conflict between father and son peaks at a board meeting where the son and his coworkers present their plan to unionize so that they can have a voice in the decisions of the company. The father, who is the chairman of the board, strongly objects to giving up his right to decide his company's direction, but the other directors vote in favor of the son's and the workers' demands.

This result emphasizes that the company is a collective organization, a community - or a "social institution" in Berle and Means's terms-where stakeholders other than the owner should have a say and, like It's a Wonderful Life, emphasizes the need for the next generation. However, when the war effort demands that the company produce airplanes rather than cars, father and son are reunited, as the father's experience is necessary to figure out how to produce thousands of planes for the nation's survival. In this way, the nation is added to the list of the key communities of family, (small) company, and town/local community. Bedford Falls in It's a Wonderful Life may be understood as a metaphor for the United States, but An American Romance makes the national reference explicit. This is also the case in All My Sons, a darker film than An American Romance, but similar in that it also has World War II as its backdrop. In both films the context of war combines a focus on the nation with one on the new generation who fought in the war and are now needed for the future.

In All My Sons, Joe is the founder and manager of the company, and his sons, Chris and Larry, were both pilots in World War II. At the beginning of the film, Larry has died and Chris returns to work at his father's factory, where he is being groomed to take over. During the war, the factory had delivered defective cylinders to warplanes, an act that caused the death of twenty-one U.S. pilots. Joe's partner was held responsible and went to jail for it, while Joe himself was deemed innocent in court. When Chris confronts his father, Joe admits that he had known of the defective cylinders. He argues that he lied for Chris's sake, so that he would be able to leave a healthy business to his son.

While Joe uses the family to legitimize his profit-focused action, the plot exposes his lack of ethics and sense of community. At the end of the film Joe recognizes that he is responsible not only for the death of twenty-one pilots, but also very specifically for that of his oldest son, Larry, who had been so ashamed to learn of his father's involvement with the defective cylinders that he killed himself. As opposed to Joe's earlier focus on business and family only, he recognizes in a big 
speech at the end of the movie that the dead pilots were "all [his] sons," likening the nation to one big family.

Joe then shoots himself, and the film ends with his wife's blessing of the relationship between Larry's former girlfriend (and the daughter of Joe's business partner) and Chris, paving the way for the next generation. Joe could not see beyond family and business and therefore failed miserably. With Chris's participation in World War II, his work in the father's factory, and his future marriage, Chris has proven his responsibility to the nation as well as to family, business, and the future.

In a 1949 Harvard Business Review article, the pollster Elmo Roper discussed the public's view of big business and how it had developed since the Great Depression. Roper reported a change in attitude: while the public had held a relatively critical view of big business in the 1930s, "a majority now appear to be convinced that the benefits of big business outweigh its disadvantages." Moreover, in the postwar period, "an increasing number of people ... now believe that management really wants to give labor a fair chance." ${ }^{26}$ Also in 1949, the dean of Harvard Business School gave three speeches in which he argued for the "doctrine of business responsibility" and the role of business leaders in the "creation of a good society.",27

Our analysis of business films in this period resonates with these points, and we contend that the films contributed to the change in the public's attitude. As we have shown, movies of the 1930s were critical of big business and the pursuit of profit for profit's sake. ${ }^{28}$ However, those of the 1940s represent a shift from a negative to a positive view_much needed in a decade filled with economic insecurity and war. ${ }^{29}$ This more positive and coherent image of business and the future of the nation stressed that the rebuilding of America needed not only business, but also entrepreneurship, the new generation, and a sense of community across the board, including companies and unions, and from the local to the national level. A better future would require a combined effort, not just an individual hunt for profit or power, as exemplified by Garner, Kane, and Potter. It seemed that business might have a role to play after all in postwar society. The focus in some of the films on generational change emphasizes this, showing how Dangos of An American Dream and Joe of All My Sons are not real villains, they just belong to the past.

Particularly in the 1940s, Hollywood films presented a positive vision of a nation working together toward a better future, where corporations accepted their role as Berle and Means's social institutions or as a "citizen in the nation," as Elmo Roper put it. ${ }^{30}$ For the movies' audiences home from the war, this would have been a vision and set of values they could identify with — if they were 
white and male, that is, as the organization man of the 1950 s was. ${ }^{31}$ Thus, as "key arbiters of public opinion," the films paved the way for a more community- or stakeholder-based American society. ${ }^{32}$ In this way, these films legitimized and provided a blueprint for a future move already underway toward a welfare society and the large-scale Chandlerian organization.

Big Corporations and the Organization Man: The 1950s and 1960s

By the 1950s the focus of the main context had changed from the national community and World War II to the Cold War. ${ }^{33}$ This change contributed to Hollywood films' more positive representation of business. More importantly, the 1950s and 1960s marked the high point of managerial and stakeholder capitalism organized around the large multidivisional corporation. Alfred Chandler defined this corporation as a "collection of units ... whose combined resources and activities are coordinated, monitored and allocated by a hierarchy of middle and top managers." ${ }^{34}$ Also, in the 1940s and 1950s, Peter Drucker, "the teacher in the grey-flannel suit," wrote about professional management and employees as resources rather than costs. ${ }^{35}$ These ideas added managerial and organizational capabilities to Taylorism and Coase's transaction cost approach, and the "organization man" was born. Thus, while this was a relatively stable period, the increasing significance of the corporation managed by a hierarchy of white male professional managers came to dominate the lives of millions of Americans. This profound change caused uncertainty and called for sensemaking.

In the 1950s, films changed their focus from the small and medium-sized family businesses of the 1940s to the large, hierarchical firm and its inner workings. The films featured conflicts related to these, and they often also included big speeches that explained how the companies worked. ${ }^{36}$ Filling in the blanks in Chandler's (human-void) description of the corporation, the movies added actual people with emotions and families, embedding them in a broader social and historical context. In doing so, they provided a blueprint for the audiences as to how to make sense of and act in these big companies. "The white-collar people slipped quietly into modern society," sociologist C. Wright Mills wrote, and these films could be seen as an attempt to make sense of and shape a new white-collar worker identity in between the collective and the individual. ${ }^{37}$

Many of the conflicts in these films arose from within the company and evolved around shareholders, stakeholders, and management, or between a production and a finance view of the business. The finance versus production conflicts had clear values attached to them: finance was 
negative and pointed backward, while production and new technology were positive forces carried by the new generation and pointing to the future.

Finance versus production is an important theme in Executive Suite, where the board of Tredway, a furniture company, is about to elect a new president. ${ }^{38}$ Don Walling, head of production, is up against L. P. Shaw, the finance and accounts manager. At the decisive board meeting, Shaw argues that "a company is answerable first and last to its stockholders," but Walling counters that the company's obligation goes far beyond the interests of the stockholders. There is an explicit "teaching moment" in Walling's big speech when he argues that "sometimes, you have to use your profits for the growth of the company, not pay them all out in dividends to impress the stockholders with your management record." The value of the two sides is clear: Walling represents the future by focusing on stakeholders, production, experimentation, and technology, while Shaw's narrow focus on the stockholders' short-term gains represents an old-fashioned way of running a company.

Walling highlights the need for a sense of community, already nurtured by the films of the 1940s, by arguing, "You can't make men work for money alone, you starve their souls when you try it. And you can starve a company to death the same way." Instead, he says, Tredway should design and produce modern furniture that will make the company and its employees proud. Walling shows his community spirit when arguing that making good furniture is "going to take every bit of wisdom and business judgment in this company, from the mills and the factories right to the top of the tower. And we're going to do it together, every one of us, right here at Tredway." The vision in Executive Suite is made clear when Walling is elected company president. He represents the businessman of the future with faith in the company and its employees. He even has a-for the 1950s - healthy and communicative relationship with his wife, while the audience never gets to know whether Shaw even has a family. ${ }^{39}$

Another perspective on the issue of generation and family is seen in The Man in the Gray Flannel Suit, where the focus is on the organization man and his choice between career and family. The protagonist, Tom Rath, is indecisive about his level of ambition in his new job at the United Broadcasting Corporation, and his boss, CEO Ralph Hopkins, counters that "big, successful" businesses are built not by people with Rath's attitude and focus on family, but rather "by men like me, who give everything they've got to it, who live it, body and soul, who lift it up regardless of anybody or anything else." In contrast to Hopkins, and the young Walling in Executive Suite, Rath chooses not to dedicate his whole life to the company. Tom's wife, Betsy, tries to push him to be 
more ambitious and urges him to never stop believing in the future. In this way she represents some of Walling's values, but Rath is not prepared to give his life to the firm. The film makes it clear that a company needs different kinds of employees and that there is a tradeoff between career and family, but it is arguably also a more complex film than Executive Suite in terms of the values of the employees of the big corporations and how the past may constrain the choices of the new generation. $^{40}$

With The Man in the Gray Flannel Suit as an exception, the future is decisively positive in the films of the 1950s, and in this way they continue an important characteristic of the previous decade's films. The future is still linked to the young generation, but also more specifically to production, which is closely related to science and technological progress. Technology has a markedly different status in the 1950s than in the 1930s - and especially in Modern Times, where technology and innovation is at best ridiculed with the failed efforts to make an "eating machine." As opposed to the caricature in Modern Times, technology and innovation in production are positive forces in several of the 1950s films. In Desk Set (1957), the only film in which an "organization woman" is featured, a computer is at first considered a threat to the jobs of the nice and knowledgeable women in the research and reference department, but it turns out that there is good use for the computer, as long as it is a supplement to the employees, not a replacement. Along the same lines, in Executive Suite furniture design is meant to improve people's lives. In Walling's big speech, he talks about products that are "scientifically and efficiently designed" and offers a good example of how production, technology, and the future interact.

To Walling, as with many of the other 1950s hero managers depicted in films, growth is not about making as much money as possible. A life's work should instead be measured by pride in the work and by the benefit to people, and business and success is not about money but about serving society. This is a stark contrast to the 1930 s films that represented business mostly as inhumane and profit focused and, at the same time, a continuation of one of the key features of the 1940s films. The quote from It's a Wonderful Life about Bailey's father caring about people, not money, is a case in point. Small business serves the local community while big business serves society.

Sabrina (1954) also combines the view of technology and the young generation as positive forces with the lack of regard for material wealth. The protagonist businessman Linus is seriousand boring compared to his flamboyant brother, David - but he is passionate about one thing, namely, the idea of using sugar to make plastic. When Linus's brother asks him why he keeps on working, as he has already "got all the money in the world," Linus argues that he is driven not by 
power or money, but by the gratification that comes from benefiting people. In his big speech, Linus explains the process: "A new product has been found, something of use to the world. A new industry moves into an undeveloped area. Factories go up. Machines are brought in. A harbor is dug, and you're in business." And with the earnings of the new invention and business, it is possible to pay for libraries, hospitals, and leisure activities such as baseball and movie theaters for people who did not previously have access to these things. According to Linus, business is good for society.

Helping people as the main objective of doing business is also a key point in The Man in the Gray Flannel Suit, when Hopkins's daughter accuses her father of being interested only in money. He replies, "No sane person is interested in money simply as money." Hopkins's main objective in the film is to fund the construction of mental health facilities and in that way put his wealth to good use. Despite their differences, several films_Executive Suite, The Man in the Gray Flannel Suit, The Power and the Prize, Patterns, and Sabrina - evolve around young business leaders who, in contrast to the older generation, are interested not in money and power per se, but in doing good by, among other things, providing new and useful products to society. These films express modernism's belief in progress, science, and the future, and their contrast to the films of the 1930 s is distinct. ${ }^{41}$

Business films of the 1950s legitimized the big corporation as a responsible citizen of the nation with a focus on the future, on new generations, production, and technology. Professional management came of age as a younger generation of socially responsible managers entered the executive suites and replaced the older generation of autocratic managers. The future generation aimed to navigate within a personally and socially healthier "work-life balance." In this narrative, Berle and Means's vision of the corporation as a social institution was realized by professional managers, as described by Chandler and Drucker. Hollywood films offered quite explicit blueprints for a new generation of ambitious white men entering the corporation as "organization men" who could identify with the narrative. These films provided pointers on how to navigate in big corporations as well as how to combine a demanding job with ideas of a modern family life, including the relationship to one's wife and children, and even how to dress and furnish one's home.

In the 1960s the grand narrative of the welfare state was still dominant, with Keynesian demand management and managerial capitalism, but a cultural counternarrative was well underway that was also visible in Hollywood films. ${ }^{42}$ Belief in science and progress came under pressure as Americans came to consider civil rights, race relations, and the Vietnam War the most important 
problems. ${ }^{43}$ This development shaped views on business as it shaped most other aspects of society. The 1960s bridged the gap between 1950s optimism about the future and 1970s full-blown criticism of society. In the relatively few business films from this decade, focus moved away from the corporation as a mostly rational, meritocratic entity. Instead, the company was represented as a jungle in which everyone looked out for himself. The first marker of this development was The Apartment (1960). ${ }^{44}$

The Apartment introduced a perception of business that merged the view of films from the 1920s and 1930s, such as Modern Times and The Crowd, with that of films from the late 1960s and 1970s. ${ }^{45}$ Even though The Apartment also shares characteristics of the 1950s films - for example, in its focus on the internal workings of the organization and on the organization man - it offers a much more pessimistic view of the corporation, where reforming business was not an option. The only way of remaining "a mensch," to use the protagonist C. C. Baxter's term, is by opting out of the company altogether. Baxter is an ordinary white-collar worker, and the managers are egoistic villains as opposed to the hero managers of the 1950s. The managers are very similar to those in the 1950s film The Solid Gold Cadillac (1956), but the decisive difference is that The Solid Gold Cadillac ends with the managers being ousted, leaving room for a new and sound management that brings the company back on track. In The Apartment, Baxter leaves the company while the corrupt management stays on.

At Consolidated Life, the insurance company in the movie How to Succeed in Business without Really Trying (1967) meritocracy does not exist, women are prey, and everyone is looking out for himself. The film shows many of the same characteristics as The Apartment and offers a bleak picture of the company as inefficient and nepotistic, a place where success depends on knowing somebody or pandering to managers. In a way, the two films illustrate the agency problem of managers looking out for themselves rather than for shareholders' interests, thus foreshadowing the rise of the market for corporate control.

Over the 1960s and early 1970s, cultural shifts in society included renewed criticism of managerial capitalism away from the general legitimizing representations of business in the films of the 1950s. This paved the way for films to represent the large-scale corporation as an alienating and negative force in society, beginning with The Apartment and From the Terrace (1960) and continuing with The Wheeler Dealers (1963), How to Succeed in Business without Really Trying, and The Arrangement (1969). Also, in Cash McCall (1960) and The Wheeler Dealers money and finance entered the picture, a development that continued in the films of the late $1980 \mathrm{~s}$. 
As a blueprint for practices in relation to the business world, the films of the 1960s no longer included the optimistic and explicit big speeches of previous decades, and their protagonists were no longer clear-cut role models. Most of the features that first appeared in 1960s films peaked in the transitional period of the 1970s and early 1980s. Movies of the 1960s and 1970s may well have contributed to the downfall of managerial capitalism and the rise of the market for corporate control. ${ }^{46}$ Whether they assisted viewers in developing a strategy for survival in corporate America is perhaps doubtful, but they did provide a counternarrative with a vision of a more polarized society, with different groups and interests with which to identify.

\section{Disillusion and Social Criticism: From 1970 to 1985}

With the breakup of Bretton Woods, the oil crisis, stagflation, and a growing recognition of the limits to growth, the dominant social narrative of the postwar period could no longer provide an adequate and convincing response to the economic, social, political, and cultural pressures of the time. The economic and cultural upheaval that had begun in the previous decade signaled an end to modernist optimism, and corporate America and managerial capitalism lost legitimacy. Lifestyle changes, limits to growth, and a general fragmentation of society contributed to a deep loss of meaning and a search for a new narrative. In the United States, concern for domestic social issues and international security problems, not least the war in Vietnam, was swept away by concerns for the economy, inflation, and unemployment. ${ }^{47}$ The earlier belief in the business world as a positive force in society and for the future was history, and so were the blueprints that had come with it. The 1970s was a transitional period in terms of not only economic turbulence but also cultural values, social structure, ideologies, and grand narratives.

The business films of the 1970s and early 1980s were mostly hostile toward business and society, which was portrayed as fragmented and alienating. ${ }^{48}$ They expanded on the pessimistic films of the 1960s but focused less on the inner workings of the company and more on the company as a key part of capitalism's problems. The business films of the 1970s expressed disillusion with the future, with consumerism and materialism, and with the traditional family (modern or not). In The Apartment, disillusion was reserved for big business. Less than ten years later, the loss of meaning had spread, focusing more on the broader societal consequences of and for business.

In The New Industrial State, John Kenneth Galbraith expressed how the corporation and its technostructure had become adept at making economic decisions and selling its products while 
noneconomic values were left behind. ${ }^{49}$ It was noneconomic values such as pollution, power, discrimination, and rent seeking that preoccupied many Americans in the 1970s, and the films of the period addressed most of these issues.

Save the Tiger (1973) refers back, it could be argued, to the 1940s films' focus on the owner-manager and his business, but combines it with the dark outlook and societal criticism of most of the other 1970s films. Jack Stoner is white and male, but he is also the troubled and very human founder of a small garment factory whose struggles with personal and business problems are framed within a critique of national fragmentation, overspending, materialism, and lack of progress.

In a life defined by mass media reporting daily on the misery of the world, Stoner and his wife are unable to communicate - a counterimage to the young, democratic, and highly communicative couples of the 1950 s films. Stoner and his wife probably share the optimist vision of those films, but the focus has changed from a bright future to a troubled past, including Stoner's participation in World War II, which continues to haunt him. Stoner meets the (new) young generation in the shape of Myra, a young woman who completely lacks both historical knowledge and purpose in life. In contrast to the young generation depicted in 1940s films, Myra does not have a job and spends her days hitchhiking up and down "the Strip." Myra seems to have found meaning in a life cut off from history, materialism, and ambition and functions as the counterimage to Stoner, who is dragged down both by material things and by history.

Parallel to Stoner's marriage and business, the nation as a community seems to be going down the drain alongside general business morale, including Stoner's own. In his big speech Stoner tries to legitimize to his business partner, Phil, why he considers burning down the factory to get the insurance money. In his speech Stoner combines the effort to protect his own life's work and the workers' jobs with the realization that the American Dream has been swallowed up by a corrupt, materialist, and money-focused society: "It's people like us, people in the middle that made this country work. And when people like ourselves get into this kind of thing ... it takes it all down. That's what's ripping the country apart!" Compared to the 1940s films in which the nation was an important part of the future, Stoner's version of the nation is in as much trouble as his firm.

Network (1976) reproduces a similar message of a nation falling apart. Network anchor Howard Beale (Peter Finch) uses his voice to criticize society: he says on prime-time TV that there is a depression and encourages viewers to shout from their windows "I am mad as hell, and I am not going to take this anymore." However, the TV network uses the event as just another opportunity to increase their ratings. In the 1970s, business films were serious dramas in which technology and the 
nation no longer promised a better future, but instead threatened societal and environmental disaster, as in The China Syndrome (1979) and Silkwood (1983). Making sense of the general crisis in values and beliefs relating not only to business but also to society in general was a difficult task, and these films only strengthened the loss of meaning and the lack of coherence.

While the shareholders versus stakeholders conflicts of the 1950s films came into focus in economic theory in the 1970s, they disappeared from Hollywood movies, and so did efforts to create continuity and coherence between the business world and society at large. In all business films from this period, corporations are shown as abusive and rent seeking or outright criminal. Norma Rae (1979) exemplifies several of the period's tendencies. The protagonist, Norma Rae, works at a cotton factory and gets involved in union activity. Management is negatively depicted, in contrast to the film's humane portraits of the factory's workers. At the film's climax, the managers have Rae arrested, and after being released from jail she explains to her children that her union work is an effort to try to secure for them a better future than hers. Rae differs from the earlier period's white male manager protagonists. Her independence and strength as a woman and a worker is emphasized when she tells her children, "Now, you kids, you know what I am. And you know that I believe in standing up for what I think is right."

The protagonist of the 1970s changes in other ways too. With collective protagonists such as workers or smaller groups of employees, as in 9 to 5 (1980), the films offer a counternarrative to the meaninglessness and exploitation experienced by workers on the factory floor and in the office. While audiences might have left the movie theaters with a negative view of business and even of U.S. society, films such as Norma Rae, 9 to 5, and Trading Places (1983) provided a blueprint and a positive vision for blue- and white-collar workers at the bottom of the hierarchy: you could do something yourself. Also, 9 to 5 and Trading Places included women and African Americans as protagonists who vetted out abusive or criminal practices such as insider trading by standing together. After the bleak 1970s, some films of the early 1980s reintroduced the hero and the potential for action and the possibility of change. However, in contrast, these later films did not present a vision that could be seen as pointing to the neoliberal period. Instead, they focused on smaller communities. The increased fragmentation of society meant that it was no longer possible to present a grand unifying vision or narrative, not even in Hollywood film. As a sign of the spread of identity politics, the subcultural community had replaced the national community in offering order and coherence with which to identify. 
From the mid-1980s, deregulation and globalization made financial markets the new driver of the economy. A neoliberal narrative gradually became established and shareholder capitalism came to constitute a new, stable regime. The films from the mid-1980s reflect this development as Berle and Means's agency problems reemerged along with the idea of efficient financial markets, this time with a focus on shareholder value. ${ }^{50}$ Conglomerates and managerial capitalism lost legitimacy, and the organization man "died at 76 " as women entered the corporate echelons and individualism surged, together with corporate raiders, private equity, and corporate downsizing. ${ }^{51}$ Rather than restoring the national coherence and sense of community of the 1940s and 1950s films, those in the late 1980 s emphasized the individual. Now it was about the mighty dollar, or, as was so eloquently put by Larry the Liquidator in Other People's Money (1991), "Whoever has the most money when he dies, wins." "Hungry" young people-yuppies_-focused on making it big rather than contributing to the nation and the community. This focus on money, so very different from the themes of the films of the 1950s, happened in the wake of the rise of modern finance, agency theory, and the so-called market for corporate control. ${ }^{52}$

Hollywood did not neglect the new trend of wheeling and dealing where "contractual relations are the essence of the firm" and firms are "simply legal fictions." $" 53$ This way of looking at "the firm" differed radically from the perspective of Berle and Means, Chandler, and Drucker. The dominant idea of the firm as "a very asset-intensive and highly vertically integrated firm, with a tight control over its employees - control that is concentrated at the top of the organizational pyramid," gradually changed. ${ }^{54}$ The "new firm," which emerged as the product of changes brought about by globalization and the Internet, represented "non-vertically integrated, human-capitalintensive organizations that operate in a highly competitive environment. ${ }^{, 55}$ From the late 1980s the corporation came under attack from corporate raiders, and once again, Hollywood films made sense of new developments in the business world.

The renewed interest in business was visible in the simple fact that from the mid-1980s the number of business films increased when compared with the 1960s and 1970s, and many of them, at least at first, centered around conflicts related to financial markets and financialization. The focus was back on the company's inner workings, where business activities generated dramatic conflicts between employees and managers, stakeholders and shareholders, managers and buyout firms. 
Conflicts between production and finance also reemerged, but this time with a more ambivalent message depending on what community viewers belonged to, as mentioned in the introduction.

The many finance films of this period coincided with the increasingly important role played by financial markets in the economy and in academic and public discourse. According to James Kwak, finance had become glamorous because of the way it was represented in films such as Wall Street (1987) and Barbarians at the Gates (1993). These films "popularized the image of the swashbuckling, individualistic, and very rich 'master of the universe.' . . At its peak, it seemed like finance was the most desirable job in the world." ${ }^{, 56}$ If any member of the public had been in doubt, the films made it abundantly clear that financial markets, in the words of Larry Summers, "don't just oil the wheels of economic growth - they are the wheels." ${ }^{, 57}$ Or, as the character Gordon Gekko puts it in Wall Street, "Greed ... is good. Greed is right, greed works."

The 1970s films' critical view of business as working against the common good had disappeared. "In Reaganite entertainment, the system works: Wall Street demonstrates American business at its worst and at its best, but its chief message is that the business community remains principled; it can, it will, and it does clean up its own act." ${ }^{, 58}$ Thus, many films depicted business and finance primarily as a positive force in society, and when it was not, it — or the legal systemmanaged to root out the bad apples whether the problem was pollution, insider trading, or other ethically tainted or criminal activities. ${ }^{59}$

Among the many business and finance films of this period, Wall Street is certainly the most iconic. Around the time Oliver Stone was working on the Wall Street manuscript, he would have been challenged to write a story that lived up to the dramatic events in real financial markets. Carl Icahn and T. Boone Pickens, among others, were active "corporate raiders" in 1987, and Michael Milken and Drexel Burnham Lambert were under investigation for insider trading. On October 19, 1987, the stock market crashed; less than two months later, Wall Street was released. ${ }^{60}$ More than any other film, Wall Street seems to have functioned as a blueprint for many young traders, from dress code to workplace behavior. The film very quickly became part of a narrative about the financial world, beyond the groups that actually worked there. As part of a sensemaking process, the general audience responded differently to the film's depiction of finance than did the traders who saw the film, some of whom - like Frank Partnoy and Pat Huddleston-found role models in its protagonists or antagonists. ${ }^{61}$

Like Wall Street, several other finance-related films depict the financiers as charming, charismatic, and rich, inevitably making the moral of these films more ambiguous and the role of 
the antagonist less clear - and certainly very different from that of the humorless finance executive Shaw in Executive Suite. Gekko in Wall Street, Edward Lewis in Pretty Woman, and Andrew Garfield in Other People's Money all live and work in surroundings where not only greed but also conspicuous consumption is good - another contrast to the critical view of materialism found in the films of the 1970s. In Barbarians at the Gates even the CEO who loses out to the private equity firm KKR can go on living his life in absolute luxury.

Larry the Liquidator in Other People's Money and Henry Kravis in Barbarians at the Gates further modify the villain's role by being presented as necessary reformers of the inefficient system of managerial capitalism. It is difficult not to agree with Garfield in his big speech to the stockholders of New England Wire and Cable: "This company is dead. . . You know why? Fiber optics, new technologies, obsolescence." However right Garfield may be, Vivian, the protagonist in Pretty Woman, expresses a point made in many films when she points out to Edward, "You don't make anything and you don't build anything." 62

If you were not driving in the fast lane of finance and could not identify with the financiers, the business films of the period pointed to two alternatives. Either you could jump on the train of creative destruction, as put so eloquently by Larry Garfield in his big speech, and become your own boss through entrepreneurship, or you could skip the idea of a career and find meaning outside of business. Given the influence of the grand rags to riches narrative of the American Dream, it is surprising that the entrepreneur had been neglected since An American Romance, but from the mid1980 s a series of films zoomed in on the entrepreneur. ${ }^{63}$ In several, the decision to start up a business is triggered by the entrepreneur's discontent with the practices in the company where he or she is employed. Rather than searching for meaning outside of business, the other alternative, these entrepreneurs, such as in Jerry Maguire (1996), aim to make sense of their own values and lives. The increased attention to innovation, entrepreneurship, and creative destruction in these films resonated with economic theory and policy where Joseph Schumpeter's work experienced a renaissance. $^{64}$

The second alternative is played out in several very different films, which show the business world from a pessimistic perspective where little hope exists of improving one's lot. Glengarry Glen Ross (1992) stands out as the epitome of hopelessness, where ruthless competition inside the firm and an abusive boss make life unbearable for most in a winner-takes-all economy. A group of real estate salesmen feel that they are constantly under pressure to perform and that they have no 
control over their own destiny. Instead, the veteran salesman Shelley Levene resorts to criminal activity and thus loses the last traces of his hope and dignity.

In Clerks (1994), Clockwatchers (1997), and Office Space (1999), work is also represented as both hard and meaningless. The development of low-paying service-sector jobs may have been the downside of the rise of the new firm. In Office Space, low-level IT worker Peter tells a therapist, "So I'm sitting in my cubicle today and I realized that ever since I started working, every single day of my life has been worse than the day before it." The solution comes from Peter's girlfriend, Joanna, who tells him, "Most people don't like their jobs. But you go out there and find something that makes you happy." These three films represent an office life that is at least as hopeless as that portrayed in The Apartment but without even the career opportunities offered to C. C. Baxter through nepotism. While financiers live the high life, the protagonists of Clerks, Clockwatchers, and Office Space are left behind, and meaning must be found outside of the workplace. ${ }^{65}$

One way of finding this meaning is through family. In The Family Man (2000), Jack Campbell gives up his Ferrari and his job as president of an investment firm when he gets a second chance to have a family. Several films in this period represent family as a positive force and a goal in itself, although the concept of family has changed since the films of the 1950s; now it includes single parents and romantic couples and not necessarily the conventional and complete package of a wife and children. ${ }^{66}$

Similar to The Family Man, the film In Good Company (2004) offers a critical view of the wheeling and dealing in the market for corporate control. The company Sports America is bought by a conglomerate led by Teddy K., who is constantly acquiring and selling companies. When he gives a meaningless speech about synergy and the company as a country, the protagonist and executive Dan calls his bluff and argues that countries, "at least democratic ones, ... have some obligation to their citizens, don't they? So, how do layoffs and bottom line thinking fit into that?" When Dan ends up winning back his old position, the importance of human capital in the new version of the firm is underlined, and so is an impatience with corporate mumbo jumbo. ${ }^{67}$ In Good Company offers a counternarrative to the wheeling and dealing-based "the firm as a nexus of contracts view" of the company. More generally, these films offered an alternative vision to audiences, among whom many must have felt squeezed themselves by the dominance of the shareholder value narrative. By then, stakeholder theory had again become a subject of academic research. ${ }^{68}$ 
Another very visible trend in this period was the emergence of women as protagonists in active, independent roles. ${ }^{69}$ The role of women in film should of course be seen as part of the general societal rethinking of gender roles that took place with the women's movement especially from the 1970s. ${ }^{71}$ These films probably contributed to a new blueprint for women in businesshere, at last, was somebody to identify with. Tess McGill's success in Working Girl (1988) shows the female audience not only how far women can get through hard (honest) work, but also how the dress code for women changes from the working-class environment of her friends to the world of investment banking. Nevertheless, the success of women in business films was often assisted by men, and the white male businessman protagonist continued to dominate.

In the thirty-four business films released between 1986 and 2008, finance seemed to dominate in the early part of the period. After 2000, films with either a positive view of the entrepreneur and the option of shaping one's own future or a cynical and resigned view of the company from employees at the bottom of the ladder appeared more frequently. Although these two types of films seem quite different, they connect in the sense that both were reactions against or alternatives to the fascinating but abusive financial world of the late 1980s and 1990s and the dramatic changes to the workplace brought about by globalization. ${ }^{72}$ Unless you were part of that privileged clique (the 0.1 percent), you were better off doing something completely different, whether it was finding meaning outside of the workplace or becoming your own boss as an entrepreneur. The vision that viewers could identify with depended entirely on what group they belonged to - a sign that society had become ever more fragmented. It was about to get worse.

After the Financial Crisis: Cynicism, Disillusion, and Resignation

The financial crisis of 2007-2008 and the Great Recession that followed caused a crisis of legitimacy for the financial and political systems and their actors. This period may be seen as the beginning of a new transitional period, where uncertainty about the future regime still exists and no new dominant narrative has yet been established. Films about business have been part of the sensemaking process necessitated by the loss of meaning after the financial breakdown. As a parallel process, several films from this period address the need to understand a new kind of firm, one that had developed over the preceding twenty years as the conglomerate, integrated, and physical capital-intensive firms came under attack. Films such as The Social Network (2010), Steve Jobs (2015), and The Intern (2015) illustrated this new firm. Thus, the financial crisis and the rise 
of the new firm called for sensemaking and formed the backdrop for many Hollywood business films after 2009.

The seventeen business films released since 2009 offered to make sense of the crisis in different ways. Six of them dealt explicitly with finance, seven dealt with entrepreneurship, and many of them had a significant authenticity effect. Among the finance films, Too Big to Fail (2011), The Wolf of Wall Street (2013), and The Big Short (2015) were "based on real events," while the narrative of Margin Call (2011) appears to have been modeled to some extent on Lehman Brothers. These films were rather concrete contributions to the general audience's sensemaking process. $^{73}$

With the financial crisis, business films began to include a new position, with cynicism and resignation as key characteristics. Business was necessary and unavoidable, but in many movies it was hardly a positive force in society and provided little hope for improvement or reform. In the films of earlier periods, reforming or leaving business were frequently used strategies, but this option was missing in many of the postcrisis films. ${ }^{74}$ The point was spelled out by Margin Call's CEO John Tuld, quoted in the introduction. Tuld's combination of cynicism and resignation is present in many of these films, but in some ways The Big Short is even more cynical and resigned because of its ironic tone and its drawing attention throughout the film to its "based on real events" quality. The Big Short further differs from the other post-financial crisis films by underlining the heavy costs of casino capitalism to ordinary people, thus pointing to the increasingly important issue of inequality in today's discourse. ${ }^{75}$

One feature of the late-1980s films was their portrayal of villains as charismatic and attractive. The post-financial crisis films take it a step further. Here, the main focus is almost entirely on the villain and only to a limited degree on his opponent, who is hardly ever defined as a hero. As a matter of fact, films like Margin Call, Arbitrage (2012), and The Big Short have no real heroes. Even the smartest financial players have lost some control in Margin Call and The Big Short, where computer algorithms and utterly incomprehensible financial instruments have taken over.

The opponent who tries to change business misbehavior typically comes from the outside. In The Wolf of Wall Street and Arbitrage, the FBI and the police constitute a counterimage to the financiers. They function as a link between the everyday world of most people and the exclusive world of business. In both films, they represent efforts to take away the privileges of the 
businesspeople but they fail and thereby confirm the general cynicism and resignation already mentioned.

Bryer, the police officer in Arbitrage, tries to convince the judge to give him an arrest warrant for the protagonist_-and villain-Robert Miller: "Twenty years, Ray. Twenty fucking years, we watch these guys - they out-lawyer us, they out-buy us. I'm fucking sick of it. Where's the consequence? The guy did it. He does not get to walk just 'cause he's on CNBC." As it turns out, Miller actually does get to walk, but only at a considerable economic cost: his wife agrees to cover for him only if he turns over the business to their daughter. In The Wolf of Wall Street the FBI representative is equally adamant about catching the protagonist, Jordan Belfort, but when he succeeds and Belfort goes to prison, it is a quite comfortable stay, and afterward, Belfort makes a business out of selling his story. The finance films of this period present little hope for serious change, let alone improvement-just more money to be made by the same people who steered the bank into trouble in the first place. Just like in the real world.

The idea that finance is a world apart and qualitatively different from where the police officers and "normal people" live is repeated in several of the films. In The Wolf of Wall Street, Belfort describes the traders" work as "obscene - in the normal world" and then adds, "But who wanted to live there?" This indicates not only the radical division, but also the almost complete lack of regard expressed by many of the protagonists for people outside of the business world. ${ }^{76}$ Other films do almost the opposite, but with the same effect. In Arbitrage, business has merged completely with family life; both spheres are depicted as highly cynical and guided by the same rules. Outside of finance, The Joneses (2009) also merges family and business in a highly cynical way in that companies go to new extremes to influence consumer choice. In Up in the Air (2009), even firing people is outsourced.

Apart from finance-related films, those that focus on the entrepreneur constituted a trend that continued and grew during the period between 1985 and 2008. If many of the finance-related films of the post-financial crisis period are cynical and resigned, most of the entrepreneur films offer a counternarrative that points to a better future. ${ }^{77}$ The Company Men (2010) stands out because it links the financial crisis and greed symbolized by a focus on shareholder value and stock options with entrepreneurship and a hope for the future. As a result of the crisis, Bobby Walker loses his job with GTX Corporation, while the CEO focuses on his shareholders and his stock options. Gene McClary, an executive at the firm, disagrees with this finance-based view. When he is fired he invests the money from his stock options in a new company and not only rehires many of 
the fired people from the old company, including Walker, but also cooperates with the union. McClary actually cares about people and community, and The Company Men offers an alternative vision to the individualism and dominance of financial markets where all the CEOs care about is the stock price and their own interests. In this way, these films contribute to the discussion of the idea of shareholder value, which is also gaining traction in academia. ${ }^{78}$

In a social group much like the employees of Clerks and Office Space, but with an entrepreneurial and resilient hero, Joy (2015) also offers a way out of hopelessness, much in line with the new focus on entrepreneurship. Other entrepreneurial films, including The Social Network, Steve Jobs, and The Founder (2016), are in some ways more similar to the cynical finance films. However, it seems clear that the films that focus on the entrepreneur in general point to a better future than do the finance films. Granted, McDonalds' Ray Kroc or Apple's Steve Jobs are not represented as sympathetic persons, but Jobs's response to Steve Wozniak's question "What do you do?" is probably precise: "I play the orchestra." Jobs's job is to conduct the musicians in such a way that the total is more than the sum of the parts, and as such he and his kind are necessary for economic and business development. In The Intern, about a successful fashion start-up established by a young woman, the generation gap is once again bridged in a way that points forward when a retired businessman is hired as an intern who ends up contributing to the value of the firm.

The financial crisis had disastrous consequences for many Americans, and in 2009 Americans massively and unsurprisingly considered unemployment, and the economy in general, the country's biggest problem. ${ }^{79}$ Like citizens in all countries hit by the financial crisis, Americans were looking for explanations that could make sense of what had happened and point them in a better direction. The business films released after 2009 participated in this process in a very direct and forceful way. In general, these films offered starkly different visions and blueprints for the future. The finance films were cynical and without much hope as they represented the financial sector and its players as villains who could hardly control their environment, not to mention themselves. But at least they got rich while everyone else was left to their own devices. The other group of films, in contrast, presented a way out of the swamp. The Company Men in particular bridged the two groups of films in that it explicitly criticized the institutional and ideological structures that had caused the malady and provided a blueprint for a better future. Much like the films made after the Great Depression and World War II, some of the post-financial crisis films point to entrepreneurship and generational cooperation as the way out. Along the way, several of 
these films also represented the new firm, which had been underway since the 1990s in parallel with the relative decline of the Chandlerian firm.

\section{Conclusions}

Business historians have paid little attention to Hollywood films, traditionally seeing them at best as reflective of society and at worst as fiction with little relevance to the study of the past. In this article we have argued that this is a serious mistake and that Hollywood films about business, released from 1928 to 2016, have been important instruments for making sense of business developments. In this article, we have argued, first, that Hollywood films are important vehicles for audiences' understanding of business in periods of uncertainty, crisis, and instability when the need for sensemaking increases. Second, we have discussed how business films, because of this characteristic, have provided cultural blueprints to be used by viewers for their own understanding, identification, and practices in relation to business in its historical context.

Business films have contributed to societal and business developments in both transitional and stable periods. With regard to the former, this has been the case following the recent financial crisis where conflicting narratives struggle to make sense of the crisis and the future. Much as the business films of the 1940s put forward a vision of the company as a social institution serving the nation, post-2009 business films have promoted two starkly different visions for the future, one cynical and resigned to financialization and another, more positive, based on entrepreneurship and the new firm. However, as was the case in the period from 1970 to 1985, Hollywood has been unable to put forward a vision that identifies business as a unifying force. That was the case in the 1940s films, but since then, centrifugal societal forces have made it unlikely that one grand narrative can act as a collective vision. Still, business films in all periods contributed to making sense of business.

In stable periods, business films contributed to more specific cases of sensemaking and the shaping of roles and practices. That was the case, for instance, with the rise of the "organization man" in the 1950s, or the financial trader in the 1980s, where Americans were introduced to the fascinating world of finance, not only as a job but as a way of life. The same has been the case in the two most recent periods, from 1985 to 2008, and after 2009. Hollywood films have provided visions that appealed not to the nation but to different cultural groups in society-financial masters 
of the universe, people employed in unfulfilling service-sector jobs, entrepreneurs, and highly educated employees of the new firm.

At the beginning of this article, we quoted Robert A. Rosenstone saying that the important thing about films is not whether they are true but whether their vision is meaningful and important. We have argued that Hollywood films about business released between 1928 and 2016 are indeed meaningful and important. Whether Margin Call's CEO John Tuld is right when he states that financial crises are unavoidable is not the point. What matters is that this narrative has the potential to influence our perception of the financial crisis and our future practices.

PER H. HANSEN is professor of business history at Copenhagen Business School and past president of the Business History Conference. His research interests include financial and economic history, as well as design history. His most recent publication is Danish Modern Furniture, 19302017. The Rise, Decline and Re-emergence of a Cultural Market Category (2018). .

ANNE MAGNUSSEN is associate professor of history at the University of Southern Denmark. Her research interests include visual representations of Spanish history, historical methods, and the history of Texas and the border. Her publications include "Between Progress and the Frontier: Authority and Mob Violence in The Gonzales Inquirer at the Turn of the Twentieth Century" in Laura Feldt and Christian Høgel, eds., Reframing Authority: The Role of Media and Materiality (2018), and "Comics as Historical Source Material: Race, Ethnicity and Power According to Texas History Movies" "Studies in Comics, 7, no. 1 (2016). 
Appendix

List of Films and Directors (in chronological order)

Year of Director

Release

\section{8-1949}

The Crowd

1928 King Vidor

American Madness

1932 Frank Capra

The Power and the Glory

1933 William K. Howard

Modern Times

1936 Charlie Chaplin

Citizen Kane

1941 Orson Welles

An American Romance

1944 King Vidor

It's a Wonderful Life

1946 Frank Capra

The Hucksters

1947

All My Sons

1948 Reiss Irving

\section{0-1969}

$\begin{array}{lll}\text { A Woman's World } & 1954 & \text { Jean Negulesco } \\ \text { Executive Suite } & 1954 & \text { Robert Wise } \\ \text { Sabrina } & 1954 & \text { Billy Wilder } \\ \text { Patterns } & 1956 & \text { Fielder Cook } \\ \text { The Man in the Gray Flannel Suit } & 1956 & \text { Mark Johnson } \\ \text { The Power and the Prize } & 1956 & \text { Henry Koster } \\ \text { The Solid Gold Cadillac } & 1956 & \text { Richard Quine } \\ \text { The Pajama Game } & 1957 & \text { George Abbott } \\ \text { Desk Set } & 1957 & \text { Walter Lang } \\ \text { Will Success Spoil Rock Hunter? } & 1957 & \text { Frank Tashlin } \\ \text { Cash McCall } & 1960 & \text { Joseph Pevney } \\ \text { From the Terrace } & 1960 & \text { Mark Robson } \\ \text { The Apartment } & 1960 & \text { Billy Wilder } \\ \text { The Wheeler Dealers } & 1963 & \text { Arthur Hiller }\end{array}$



How to Succeed in Business without Really Trying 1967
David Swift
The Arrangement
1969 Elia Kazan

\section{0-1985}

Save the Tiger

1973 John G. Avildsen

Network

1976 Sidney Lumet

Norma Rae

1979 Martin Ritt

The China Syndrome

1979 James Bridges

9 to 5

1980 Colin Higgins

Trading Places

1983 John Landis

Silkwood

1983 Mike Nichols

\section{6-2008}

Baby Boom

1987 Charles Shyer

The Secret of My Success

1987 Herbert Ross

Wall Street

1987 Oliver Stone

Big Business

1988 Jim Abrahams

Tucker: The Man and His Dream

1988 Francis Ford Coppola

Working Girl

1988 Mike Nichols

Pretty Woman

1990 Garry Marshall

Other People's Money

1991 Norman Jewison

Glengarry Glen Ross

1992 James Foley

Barbarians at the Gate

1993 Glenn Jordan

Clerks

1994 Kevin Smith

Disclosure

1994 Barry Levinson

The Hudsucker Proxy

1994 Joel Coen

Jerry Maguire

1996 Cameron Crowe

Clockwatchers

1997 Jill Sprecher

Civil Action

1998 Steven Zaillian

You've Got Mail

1998 Nora Ephron

Office Space

1999 Mike Judge

Pirates of Silicon Valley

1999 Martin Burke 
Rogue Trader

The Insider

Boiler Room

Erin Brockovich

The Family Man

What Women Want

Two Weeks Notice

The Aviator

In Good Company

Thank You for Smoking

A Good Year

The Devil Wears Prada

The Pursuit of Happyness

There Will Be Blood

Cadillac Records

2009-2016

The Joneses

The Informant!

Up in the Air

Casino Jack

The Company Men

The Social Network

Wall Street: Money Never Sleeps

Margin Cal

Too Big to Fail

Arbitrage

Jobs

The Wolf of Wall Street

Joy

Steve Jobs

The Big Short
1999

1999

2000

2000

2000

2000

2002

2004

2004

2005

2006

2006

2006

2007

2008

2009

2009

2009

2010

2010

2010

2010

2011

2011

2012

2013

2013

2015

2015

2015
James Dearden

Michael Mann

Ben Younger

Steven Soderbergh

Brett Ratner

Nancy Meyers

Marc Lawrence

Martin Scorcese

Paul Weitz

Jason Reitman

Ridley Scott

Davis Frankel

Gabriele Muccino

Paul Thomas Anderson

Martin Darnell
Derrick Borte

Steven Soderbergh

Jason Reitman

George Hickenlooper

John Wells

David Fincher

Oliver Stone

J. C. Chandor

Curtis Hanson

Nicholas Jarecki

Joshua Michael Stern

Martin Scorcese

David O. Russell

Danny Boyle

Adam McKay 
The Intern

The Founder

Films we have been unable to locate:

The Wolf of Wall Street

Wall Street

Looking Forward

The Devil and Miss Jones
2015

2016
Rowland V. Lee

R. William Neill

Clarence Brown

Sam Wood

${ }^{1}$ Alessandra Stanley, "A Booming Market for Art That Imitates Life after the Financial Crisis," New York Times, 7 Feb. 2016.

${ }^{2}$ Financial Crisis Inquiry Commission (FCIC), The Financial Crisis Inquiry Report: Final Report of the National Commission on the Causes of the Financial and Economic Crisis in the United States (Washington, D.C., 2011).

${ }^{3}$ Ibid., xvii.

${ }^{4}$ Robert A. Rosenstone, History on Film/Film on History, 2nd ed. (Harlow, U.K., 2012), 55. See also Alan Munslow, "Film and History: Robert A. Rosenstone and History on Film/Film on History," Rethinking History 11, no. 4 (2007): 565-75.

${ }^{5}$ The concept of sensemaking is mostly attributable to Karl E. Weick, Sensemaking in Organizations (Thousand Oaks, Calif., 1995). For recent discussions of sensemaking, see Sally Maitlis and Marlys Christianson, "Sensemaking in Organizations: Taking Stock and Moving Forward," Academy of Management Annals 8, no. 1 (2014): 57-125; and Robin Holt and Joep Cornelissen, "Sensemaking Revisited," Management Learning 45, no. 5 (2014): 52539. We use the sensemaking approach at the societal level and focus on how narratives create order and direction in, and ascribe meanings and causality to, events in situations of uncertainty. See Per H. Hansen, "Making Sense of Financial Crisis and Scandal: A Danish Bank Failure in the First Era of Finance Capitalism," Enterprise \& Society 13, no. 3 (2012): 672-706; and Matthew W. Seeger and Timothy L. Sellnow, Narratives of Crisis: Telling Stories of Ruin and Renewal (Stanford, 2016).

${ }^{6}$ As in many other studies, the influence of business films on the audience's worldview and behavior is an implicit premise. See John Corner, "Influence: The Contested Core of Media Research," in Mass Media and Society, 3rd ed., ed. James Curran and Michael Gurevitch (London, 2000), 376. See also Emma Bell, Reading Management and Organization in Film (New York, 2008), 203. For an analysis of different groups of viewers' perceptions of films, see JoEllen Shively, "Cowboys and Indians: Perceptions of Western Films among American Indians and Anglos," American Sociological Review 57, no. 6 (1992): 725-34 
${ }^{7}$ Steven Perlberg, "We Saw 'Wolf of Wall Street' with a Bunch of Wall Street Dudes and It Was Disturbing," Business Insider, 19 Dec. 2013, http://www.businessinsider.com/banker-pros-cheer-wolf-of-wall-street-2013-12.

${ }^{8}$ Francesco Guerrera, "The 'Wall Street' Effect," Financial Times Weekend, 25-26 Sept. 2010. See also Geraldine Fabrikant, "Wall Street Reviews 'Wall Street," New York Times, 10 Dec. 1987; Josh Sims, "Brace Yourself for Suspenders," Financial Times, 14 Dec. 2007; and Colin Cameron, "Power, Sex and Suits," Financial Times, 15 Dec. 2007.

${ }^{9}$ Grant McCracken, Culture and Consumption: New Approaches to the Symbolic Character of Consumer Goods and Activities (Bloomington, Ind., 1988), 74.

${ }^{10}$ For a recent discussion of performativity, see Fabian Muniesa, The Provoked Economy: Economic Reality and the Performative Turn (London, 2014). In relation to business history, see Per H. Hansen, "Business History: A Cultural and Narrative Approach," Business History Review 86, no. 4 (2012): 693-717; and Per H. Hansen, "From Finance Capitalism to Financialization: A Cultural and Narrative Perspective on 150 Years of Financial History," Enterprise \& Society 15, no. 4 (2014): 605-42. Regarding epistemic communities, see Peter M. Haas, "Introduction: Epistemic Communities and International Policy Coordination," International Organization 46, no. 1 (1992): 1-35.

${ }^{11}$ The idea that films and popular culture generally participate in shaping perceptions, identities, and practices is not particularly related to business and film, nor is it new. On business films, see, for example, Bell, Reading Management, 1, 23, 32-37; Barbara Czarniawska and Carl Rhodes, "Strong Plots: Popular Culture in Management Practice and Theory," in Management Education and the Humanities, ed. Pasquale Gagliardi and Barbara Czarniawska (Cheltenham, U.K., 2006), 199; Julie Levinson, The American Success Myth on Film (New York, 2012), 18; Bert Spector, "The Man in the Gray Flannel Suit in the Executive Suite: American Corporate Movies in the 1950s," Journal of Management History 14, no. 1 (2008): 89; Steven M. Shugan, “Antibusiness Movies and Folk Marketing," Marketing Science 25, no. 6 (2006): 681; Glenn E. Bugos, "Organizing Stories of Organizational Life: Four Films on American Business," Studies in Cultures, Organizations and Societies 2, no. 1 (1996): 111-12, 126; Larry E. Ribstein, "Wall Street and Vine: Hollywood's View of Business," Managerial and Decision Economics 33, no. 4 (2012): 212; and Martin Parker, Against Management: Organization in the Age of Managerialism (Oxford, 2002), 157. Within historical research, David Carr has argued in favor of continuities between narrative, everyday experience, and action; see Carr, Time, Narrative, and History (Bloomington, Ind., 1986), 16. See also Rosenstone, History on Film, 4; Robert M. Rosenstone, Visions of the Past: The Challenge of Film to Our Idea of History (Cambridge, Mass., 1995), 22; and Jean-Rolph Trouillot, Silencing the Past: Power and the Production of History (Boston, 1995), 21. For a business historian's view on film and history, see Peter Miskell, "Historians and Film," in Making History: An Introduction to the History and Practices of a Discipline, ed. Peter Lambert and Phillipp Schofield (London, 2004). For a discussion of narratives and business history, see Hansen, "Business History."

${ }^{12}$ Bert Spector, "A Crack the Cold War Consensus: Billy Wilder's The Apartment," Management \& Organizational History 4, no. 2 (2009): 199; Bugos, "Organizing Stories,” 111-12; Larry May, The Big Tomorrow: Hollywood and the Politics of the American Way (Chicago, 2000): 263-65.

${ }^{13}$ On representations of management and organization in Hollywood films over time, see Bell, Reading Management. On how Hollywood movies represent business and the "American dream," see Levinson, American Success Myth; and Jack Boozer, Career Movies: American Business and the Success Mystique (Austin, Tex., 2002). 
However, none of these three analyses addresses the more general category of business in society and how films make sense of business and uncertainty. Other scholars discuss Hollywood as a business in itself; see, for instance, Douglas Gomery, "Film and Business History: The Development of an American Mass Entertainment Industry," Journal of Contemporary History 19, no. 1 (1984): 89-103; Gerben Bakker, "Stars and Stories: How Films Became Branded Products," in An Economic History of Film, ed. John Sedgwick and Michael Pokorny (Abingdon, U.K., 2005); Gerben Bakker, "How Motion Pictures Industrialized Entertainment," Journal of Economic History 72, no. 4 (2012): 1036-63; and Parker, Against Management, 135. On business films as teaching tools in business studies, see Bell, Reading Management; Andrea Werner, "Margin Call': Using Film to Explore Behavioural Aspects of the Financial Crisis," Journal of Business Ethics 122, no. 4 (2014): 643-54; Kenneth E. Aupperle and Steven M. Dunphy, "Managerial Lessons for a New Millenium: Contributions from Chester Barnard and Frank Capra," Management Decision 39, no. 2 (2001): 156-64; and Oliver F. Williams, ed., The Moral Imagination: How Literature and Films Can Stimulate Ethical Reflection in the Business World (Notre Dame, Ind., 1997).

Among the few studies that present a general view of business representations in Hollywood film, some argue that Hollywood films are anticapitalist, and others, that they are procapitalist. For the former, see Ribstein, "Wall Street and Vine"; Larry E. Ribstein, ed., "Imagining Wall Street," special issue, Virginia Law and Business Review 1, no. 2 (2006); Edward W. Younkins, "Business through Literature and Film," Le Québécois Libre, no. 308 (15 Feb. 2013), http://www.quebecoislibre.org/13/130215-7.html; and Shugan, "Antibusiness Movies." For the latter, see Levinson, American Success Myth, 65-108; Elena Oliete-Aldea, "Fear and Nostalgia in Times of Crisis: The Paradoxes of Globalization in Oliver Stone's Money Never Sleeps," Culture Unbound 4, no. 2 (2010): 347-66; Bruce Baum, "Hollywood's Crisis of Capitalism 2011: Inside Job, The Company Men, and the Myth of Good Capitalism," New Political Science 33, no. 4 (2011): 603-12; and Norman K. Denzin, "Reading 'Wall Street': Postmodern Contradictions in the American Social Structure," in Theories of Modernity and Postmodernity, ed. Brian S. Turner (London, 1990), $31-44$.

${ }^{14}$ See Hansen, "From Finance Capitalism"; and Parker, Against Management, 134-58.

${ }^{15}$ Our selection of films resembles the "snowball sampling" used in Bell, Reading Management, 8-9. It is based on relevant literature, the Internet Movie Database (http://www.imdb.com/), and the American Film Institute's catalog of feature films (http://www.afi.com/members/catalog/). For a definition of Hollywood films, see John Lewis, American Film: A History (New York, 2008), 92; and John Belton, American Cinema/American Culture (New York, 2013), 24.

${ }^{16}$ On narratives and the elements of events, actors, time, and location, see Mieke Bal, Narratology: Introduction to the Theory of Narratives (Toronto, 2009).

${ }^{17}$ For more detailed analyses of some of the individual films, see Levinson, American Success Myth; Boozer, Career Movies; and Bell, Reading Management.

${ }^{18}$ On the Hollywood system and organizing of filmmaking, see Bell, Reading Management, chap. 2; and May, The Big Tomorrow. Cinematography, music, choice of lead actors, and other issues also affected how the films represented business; see Bell, Reading Management, 13-64; and Levinson, American Success Myth, 1-20. However, for the purposes of this article, we argue that analysis of the films' narratives is an appropriate analytical strategy. 
${ }^{19}$ Adolf Berle and Gardiner Means, The Modern Corporation and Private Property (New York, 1932); Ronald Coase, "The Nature of the Firm," Economica 4, no. 16 (1937): 386-405. For a discussion of Berle and Means's point about the corporation as a social institution, see Gerald F. Davis, "The Twilight of the Berle and Means Corporation," Seattle University Law Review 34, no. 4 (2011): 1121-38.

${ }^{20}$ US Senate Committee on Banking and Currency, The Pecora Report: The 1934 Report on the Practices of Stock Exchanges from the "Pecora Commission" (Washington, D.C., 1934); Michael Perino, The Hellhound of Wall Street: How Ferdinand Pecora's Investigation of the Great Crash Forever Changed American Finance (New York, 2010).

${ }^{21}$ See also May, The Big Tomorrow, 4. The Hucksters (1947) corresponds to some extent with the critical approach to big business, as the protagonist decides to leave the world of marketing.

${ }^{22}$ Belton, American Cinema, 137.

${ }^{23}$ See also Levinson, American Success Myth, 70-75; and Bell, Reading Management, 19.

${ }^{24}$ See also Bugos, “Organizing Stories,” 112-15; and Levinson, American Success Myth, 42-43.

${ }^{25}$ About the latter, see Parker, Against Management, 139-40.

${ }^{26}$ Elmo Roper, "The Public Looks at Business," Harvard Business Review 27, no. 2 (1949): 169, 170, 171.

${ }^{27}$ Donald K. David, "Business Responsibilities in an Uncertain World," Harvard Business Review 27, no. 3 (1949): $1-8$.

${ }^{28}$ Suspicion of big business, robber barons, Wall Street versus Main Street, and financial speculation all go back to the nineteenth century; see Richard John, "Robber Barons Redux: Antimonopoly Reconsidered," Enterprise \& Society 13, no. 1 (2012): 1-38.

${ }^{29}$ Gregor Aisch and Alicia Parlapiano, "What Do You Think Is the Most Important Problem Facing This Country Today?," New York Times, 27 Feb. 2017.

${ }^{30}$ Roper, "Public Looks at Business," 169.

${ }^{31}$ For a discussion of the generation of 1950 s executives and their values, see Brian R. Cheffins, "Corporate Governance since the Managerial Capitalism Era," Business History Review 89, no. 4 (2015): 717-44.

${ }^{32}$ Batia Wiesenfeld and Gino Cattani, "Business through Hollywood's Lens," Harvard Business Review, Oct. $2010,146-47$.

${ }^{33}$ See Spector, "American Corporate Movies"; Spector, "Crack the Cold War Consensus"; and John A. Noakes, "Official Frames in Social Movement Theory: The FBI, HUAC, and the Communist Threat in Hollywood," Sociological Quarterly 41, no. 4 (2000): 662-63.

${ }^{34}$ Alfred D. Chandler Jr., Scale and Scope (Cambridge, Mass., 1990), 15. See also Alfred D. Chandler Jr., Strategy and Structure: Chapters in the History of the American Industrial Enterprise (Cambridge, Mass., 1962) and The Visible Hand (Cambridge, Mass., 1977).

${ }^{35}$ Peter Drucker, The Concept of the Corporation (New York, 1946); Peter Drucker, The Practice of Management (New York, 1954). The quote is from Drucker, "Trusting the Teacher in the Grey-Flannel Suit," Economist, 17 Nov. 2005.

${ }^{36}$ Examples include A Woman's World (1954), Sabrina (1954), Executive Suite (1954), The Solid Gold Cadillac (1956), and Patterns (1956). 
${ }^{37}$ C. Wright Mills, White Collar: The American Middle Classes (New York, 1951), ix. See also William H. Whyte Jr., The Organization Man (New York, 1956); Spector, "American Corporate Movies," 94-95; Levinson, American Success Myth, 75-92; and Bell, Reading Management, 95-96.

${ }^{38}$ Cash McCall (1960) refers to a similar conflict.

${ }^{39}$ Patterns (1956) and The Solid Gold Cadillac (1956) are other examples of how good management that is responsible to society is possible, especially with the new generation at the helm. See also Spector, "American Corporate Movies," 96-99. For an alternative (more pessimistic) interpretation, see Levinson, American Success Myth, 87.

${ }^{40}$ The relationship between family and work, as well as the issue of women in the marriage, is also addressed in A Woman's World (1954).

${ }^{41}$ Other business films of the 1950s addressed issues such as the introduction of new technology, in Desk Set (1957); labor unions versus management, in The Pajama Game (1957); and career versus family, in Will Success Spoil Rock Hunter? (1957).

${ }^{42}$ See May, The Big Tomorrow, chap. 6.

${ }^{43}$ Aisch and Parlapiano, "Most Important Problem."

${ }^{44}$ Martin Parker argues that The Apartment did not question "the overall legitimacy of the organization." Parker, Against Management, 140-41. However, Bert Spector convincingly sees The Apartment as the beginning of a "significant ground shift" that took place in the 1960s. Spector, "American Corporate Movies," 100.

${ }^{45}$ Spector, "Crack the Cold War Consensus."

${ }^{46}$ For discussion of this process, see Cheffins, "Corporate Governance"; and George P. Baker and George David Smith, The New Financial Capitalists: Kohlberg, Kravis Roberts and the Creation of Corporate Value (New York, 1998).

${ }^{47}$ Aisch and Parlapiano, "Most Important Problem."

${ }^{48}$ Belton, American Cinema, 373. See also Lewis, American Film, 291.

${ }^{49}$ John Kenneth Galbraith, The New Industrial State (Boston, 1967).

${ }^{50}$ Michael Jensen and William H. Meckling, "Theory of the Firm: Managerial Behavior, Agency Costs and Ownership Structure," Journal of Financial Economics 3, no. 4 (1976): 305-60; Michael Jensen, "Takeovers: Folklore and Science," Harvard Business Review, Nov.-Dec. 1984, 109-21.

${ }^{51}$ See, for instance, with telling titles, "The Organization Man, DEAD AT 76," Journal of Business Strategy 18, no. 6 (1997): 19-23; and Amanda Bennett, The Death of the Organization Man (New York, 1990).

${ }^{52}$ See Baker and Smith, New Financial Capitalists; Hansen, "From Finance Capitalism"; and Cheffins, "Corporate Governance."

${ }^{53}$ Jensen and Meckling, "Theory of the Firm," 310.

${ }^{54}$ Luigi Zingales, “In Search of New Foundations,” Journal of Finance 55, no. 4 (2000): 1624.

${ }^{55}$ Ibid., 1642-3.

${ }^{56}$ James Kwak, "Cultural Capture and the Financial Crisis," in Preventing Regulatory Capture: Special Interest Influence and How to Limit It, ed. Daniel Carpenter and David A. Moss (Cambridge, Mass., 2013). 
${ }^{57}$ Quoted in Gerald F. Davis, "Politics and Financial Markets," in The Oxford Handbook of the Sociology of Finance, ed. Karin Knorr Cetina and Alex Preda (Oxford, 2012): 44.

${ }^{58}$ Belton, American Cinema, 393-94. See also Parker, Against Management, 152-53; and Judith Williamson, “Up Where You Belong': Hollywood Images of Big Business in the 1980s," in Enterprise and Heritage: Crosscurrents of National Culture, ed. John Corner and Sylvia Harvey (London, 1991).

${ }^{59}$ See Trading Places (1983), Wall Street (1987), Working Girl (1988), Barbarians at the Gates (1993), Civil Action (1998), The Insider (1999), Rogue Trader (1999), Boiler Room (2000), Erin Brockovich (2000), Two Weeks Notice (2002), and In Good Company (2004).

${ }^{60}$ Bugos, "Organizing Stories," 123. On the rise of finance and LBOs in the context of Wall Street, see Beverly Merrill Kelley, Reelpolitik Ideologies in American Political Film (Lanham, Md., 2012): 43-74.

${ }^{61}$ Francesco Guerrera, "How 'Wall Street' Changed Wall Street,” Financial Times, 24 Sept. 2010; and Kelley, Reelpolitik Ideologies, 65-70. For a critical academic analysis of Wall Street, see Denzin, "Reading 'Wall Street."”

${ }^{62}$ The same point is made in Wall Street by Gekko ("I create nothing. I own") and in Other People's Money (1991) by Garfield (“I don’t make anything? I am making you money”).

${ }^{63}$ Examples include Baby Boom (1987), Tucker: A Man and His Dream (1988), Jerry Maguire (1996), Pirates of Silicon Valley (1999), The Aviator (2004), The Pursuit of Happyness (2006), There Will Be Blood (2007), and Cadillac Records (2008).

${ }^{64}$ Thomas K. McCraw, Prophet of Innovation: Joseph Schumpeter and Creative Destruction (Cambridge, Mass., 2007)

${ }^{65}$ Films such as The Secret of My Success (1987) and Thank You for Smoking (2005) also signal meaninglessness and cynicism in different ways.

${ }^{66}$ See, for instance, Baby Boom (1987), Pretty Woman (1990), You've Got Mail (1998), Two Weeks Notice (2002), The Pursuit of Happyness (2006), and A Good Year (2006).

${ }^{67}$ On the "new firm," see Zingales, "New Foundations."

${ }^{68}$ Thomas Donaldson and Lee E. Preston, "The Stakeholder Theory of the Corporation: Concepts, Evidence, and Implications," Academy of Management Review 20, no. 1 (1995): 65-91; R. Edward Freeman, Strategic Management: A Stakeholder Approach (Boston, 1984).

${ }^{69}$ Examples include Baby Boom (1987), Working Girl (1988), Erin Brockowich (2000), and The Devil Wears Prada (2006). With regards to racial minorities, Eddie Murphy in Trading Places (1983) and Will Smith in The Pursuit of Happyness (2006) seem to be two exceptions to the rule.

${ }^{71}$ On representations of women in films, see Bell, Reading Management, 139-59.

72 Zingales, "New Foundations."

${ }^{73}$ The based-on-real-events film phenomenon accelerated with the financial crisis, but the trend was also clear in business films outside of finance, for instance, The Informant! (2009), The Social Network (2010), Casino Jack (2010), Jobs (2013), Joy (2015), Steve Jobs (2015), and The Founder (2016).

${ }^{74}$ For example, Up in the Air (2009), The Joneses (2009), The Informant! (2009), Arbitrage (2012), and The Wolf of Wall Street.

${ }^{75}$ The obvious reference is Thomas Piketty, Capital in the Twenty-First Century (Cambridge, Mass., 2014). 
${ }^{76}$ Seen also in Casino Jack (2010), Wall Street: Money Never Sleeps (2010), and Margin Call (2011).

${ }^{77}$ Examples include The Company Men (2010), Jobs (2013), Joy (2015), Steve Jobs (2015), and The Intern (2015).

${ }^{78}$ See Lynn Stout, The Shareholder Value Myth: How Putting Shareholders First Harms Investors, Corporations, and the Public (San Francisco, 2012); and Gautam Mukunda, "The Price of Wall Street's Power," Harvard Business Review, June 2014, 70-78.

${ }^{79}$ Aisch and Parlapiano, "Most Important Problem." 